\title{
The Roles of Thwaites' and Marais' Diagnostic Scoring Indexes and a Clinical Prediction Model in the Diagnosis of Tuberculous Meningitis
}

\section{Tüberküloz Menenjit Tanısında Thwaites ve Marais'in Tanı Skor İndeksleri ve Klinik Bir Tahmin Modelinin Rolü}

\author{
(D) Şemsi Nur Karabela1 , (D) Gülten Ünlü2 , (D) Sevtap Şenoğlu¹, (D) Esra Canbolat Ünlü11, (1) Ramazan Korkusuz¹, \\ (D) Kadriye Kart Yaşar ${ }^{1}$ \\ ${ }^{1}$ University of Health Sciences Turkey, Bakırköy Dr. Sadi Konuk Training and Research Hospital, Clinic of Infectious Diseases and Clinical \\ Microbiology, İstanbul, Turkey \\ ${ }^{2}$ University of Health Sciences Turkey, Derince Training and Research Hospital, Clinic of Infectious Diseases and Clinical Microbiology, Kocaeli, \\ Turkey
}

\begin{abstract}
Objective: Tuberculous meningitis (TBM) is the most severe form of extra pulmonary tuberculosis. Bacteriological confirmative tests based on mycobacterial cultures or polymerase chain reaction tests are time-consuming process may not help diagnose every TBM patient. Therefore, practical and easily applicable scoring systems may be helpful in the early diagnosis of TBM and should be applied in the clinical follow-up process.

Methods: The features of 20 patients with TBM were retrospectively evaluated according to the Thwaites' diagnostic scoring indexes (TDSI) and Marais' diagnostic scoring indexes (MDSI) beside a clinical prediction model (CPM) in this study. MDSI, CPM, viral, brucellar, and fungal etiologies were excluded by microscopic, serological, and molecular examinations of cerebrospinal fluid (CSF) and blood in all patients.

Results: All patients were assessed for TBM according to TDSI (100\%). Of these, 5 (25\%) were considered probable TBM, and 15 (75\%) were possible TBM, according to MDSI. The scores were greater than or equal to 6 in all the cases with TBM by CPM, 13 of which were scored as 9 points (65\%).
\end{abstract}

Conclusion: According to the outcomes of our study, the TDSI, MDSI, and CPM assessment methods are easily applicable and helpful techniques for rapid and accurate TBM diagnosis.

Keywords: Tuberculosis, tuberculous meningitis, Thwaites, Marais, clinical prediction model

\section{öz}

Amaç: Tüberküloz menenjit (TBM), ekstrapulmoner tüberkülozun en ciddi formudur. Mikobakteriyel kültür ve polimeraz zincir reaksiyonu testlerine dayanan bakteriyolojik doğrulama testleri hem zaman alıcı testlerdir hem de TBM'li her hastanın tanısında yardımcı olmayabilir. Bu yüzden, pratik ve uygulaması kolay diagnostik skorlama indeksleri TBM'nin erken tanısında faydalı olabilir ve klinik takipte kullanılmalıdır.

Gereç ve Yöntem: Bu çalışmada 20 TBM hastasının özellikleri, klinik tahmin modelinin yanı sıra Thwaites ve Marais'in diagnostik skorlama indekslerine (TDSI ve MDSI) göre retrospektif olarak değerlendirildi. Tüm hastalarda BOS ve kanın mikroskobik, serolojik ve moleküler incelemeleri ile viral, brusellar ve fungal etiyolojiler dışlandı.

Tartışma: Tüm hastalar TDSI'ya göre (\%100) TBM olarak değerlendirilirken, sırasıyla 5'i (\%25) ve kalan 15'i (\%75) MDSI'ye göre olası TBM ve olası TBM olarak değerlendirildi. CPM ile TBM olan tüm olgularda puanlar 6'dan büyük veya eşit olup, 13'ü 9 puan (\%65) olarak puanlanmıştır.

Sonuç: Çalışmamızın sonuçlarına göre TDSI, MDSı ve CPM değerlendirme yöntemleri TBM'nin hızlı ve doğru teşhisi için uygulanması kolay ve kullanışı tekniklerdir.

Anahtar Kelimeler: Tüberküloz, tüberküloz menenjit, Thwaites, Marais, klinik tahmin modeli

Address for Correspondence: Kadriye Kart Yaşar, University of Health Sciences Turkey, Bakırköy Dr. Sadi Konuk Training and Research Hospital, Clinic of Infectious Diseases and Clinical Microbiology, İstanbul, Turkey

Phone: +90 5324663609 E-mail: hkkyasar@gmail.com ORCID ID: orcid.org/0000-0003-2963-4894

Cite as: Karabela ŞN, Ünlü G, Şenoğlu S, Canbolat Ünlü E, Korkusuz R, Kart Yaşar K. The Roles of Thwaites' and Marais' Diagnostic Scoring Indexes and a Clinical Prediction Model in the Diagnosis of Tuberculous Meningitis. Med J Bakirkoy 2021;17:221-226

Received: 06.07.2021

Accepted: 02.08.2021 


\section{INTRODUCTION}

Tuberculous meningitis (TBM) is the most severe form of tuberculosis (TB), as its exact incidence and prevalence rates are unknown. However, its incidence is expected to be relatively high, especially in children, human immunodeficiency viruses-infected individuals, and people living in countries with a high burden of pulmonary TB (1). According to the 2019 World Health Organization (WHO) Global TB report, approximately 10 million people were diagnosed with TB in 2018. They lived mainly in Southeast Asia (44\%) and Africa (24\%). Extra pulmonary TB (EPTB) constitutes $15 \%$ of all cases. Nevertheless, the patients from high-incidence countries may manifest a higher prevalence rate. Turkey is among the countries with a prevalence rate of EPTB higher than $30 \%$ (2). In Turkey, the total case rate is 15.6 per hundred thousand in 2016, according to the 2018 report of TB (3). Globally, about 1.5 million TB-related deaths occurred worldwide. Without the prompt diagnosis and early treatment of TBM, mortality and morbidity rates are exceptionally high. Also, delayed diagnosis and subsequent therapy significantly contribute to the current high mortality rate $(1,4-6)$.

The gold standard of TBM diagnosis is the identification of Mycobacterium tuberculosis bacilli in the cerebrospinal fluid (CSF). Novel culture methods based on liquid media, such as mycobacteria growth indicator tube, have higher positivity rates than the classical Löwenstein-Jensen method. However, the sensitivity and positivity rates of the current laboratory confirmation methods based on mycobacterial culture or polymerase chain reaction (PCR) tests do not exceed $60 \%$ (7). These methods require a long-lasting process and a well-trained authorized staff capable of using specific equipment for a positive result (8). Therefore, scoring indexes or clinical prediction models based on clinical, laboratory, radiological, and CSF findings have been developed by researchers (9-11). This study aims to evaluate 20 patients with TBM according to the Thwaites' scoring indexes (TDSI) and Marais' scoring indexes (MDSI) and a clinical prediction model (CPM) and to assess these practical diagnostic approaches to diagnose TBM.

\section{METHODS}

This retrospective study included patients with TBM over 18 years of age followed in our hospital between 2015 and 2019. TBM was diagnosed based on clinical, CSF, radiological, and laboratory findings in the cases that presented the clinical picture of meningitis (12) (Table 1). Viral, brucellar, and fungal etiologies were excluded by microscopic, serological, and molecular examinations of
Table 1. Diagnostic criteria for TBM and ABM (12)

\begin{tabular}{|c|c|}
\hline TBM & ABM \\
\hline $\begin{array}{l}\text { Mycobacterium tuberculosis isolation } \\
\text { from CSF or clinical signs of meningitis }\end{array}$ & $\begin{array}{l}\text { Isolation of bacterial } \\
\text { agent from CSF } \\
\text { or clinical signs of } \\
\text { meningitis }\end{array}$ \\
\hline $\begin{array}{l}\text { With negative Gram or Indian ink stain } \\
\text { and negative culture for bacterial or } \\
\text { fungal agents, in the presence of at } \\
\text { least one of the following features: }\end{array}$ & $\begin{array}{l}\text { In the presence of } \\
\text { all of the following } \\
\text { features: }\end{array}$ \\
\hline $\begin{array}{l}\text { Cranial imaging findings compatible } \\
\text { with TB }\end{array}$ & Pleocytosis in CSF \\
\hline $\begin{array}{l}\text { The signs of accompanying pulmonary } \\
\text { TB }\end{array}$ & $\begin{array}{l}\mathrm{CSF} / \text { plasma glucose } \\
\text { ratio }<50 \%\end{array}$ \\
\hline Positive family history for TB & $\begin{array}{l}\text { Negative CSF and } \\
\text { blood cultures }\end{array}$ \\
\hline Close contact with an active TB case & - \\
\hline $\begin{array}{l}\text { Clinical response to antituberculous } \\
\text { therapy }\end{array}$ & $\begin{array}{l}\text { Clinical response to } \\
\text { non-specific therapy }\end{array}$ \\
\hline
\end{tabular}

CSF and blood. Ethics Committee approval was obtained from University of Health Sciences Turkey, Bakırköy Dr. Sadi Konuk Training and Research Hospital (2018/470; 201823-18). Since the study was retrospective, patient consent forms were not obtained.

The TDSI, MDSI, and a clinical prediction method supported the diagnosis (Tables 2,3). TDSI included five clinical and laboratory variables. The cases with scores $\leq 4$ were considered as having TBM, whereas patients with scores $>4$ were classified as bacterial meningitis, according to TDSI. MDSI included criteria for clinical and biochemical analysis of CSF, cerebral imaging, and evidence of extra-neural tuberculosis. Patients with scores of $\geq 12$ were considered probable, whereas those with scores of 6-11 were evaluated as possible TBM, according to MDSI criteria. The cases with culture or PCR positivity were assessed as "definite TBM." The following four rules were accepted in the CPM for TBM (11): 1) Duration of symptoms before admission $\geq 5$ days; 2) neurological stage II and III; 3) CSF/blood glucose ratio $\leq 0.5$; 4) CSF protein level $\geq 100 \mathrm{mg} / \mathrm{dL}$. This model accurately predicts $89.1 \%$ of cases with TBM, according to Hristea et al. (11). TBM staging was performed according to the British Medical Research Council criteria: Patients with mild and non-specific symptoms were considered as stage I, those with mild alteration of consciousness or with cranial nerve palsies were considered as stage II, and those with major neurological deficits or coma were considered as Stage III (13). All cases were treated with classical four-drug antituberculous therapy for 12 months and with additional 


\begin{tabular}{ll}
\hline \multicolumn{2}{l}{ Table 2. Thwaites' diagnostic scoring index (9) } \\
\hline Parameters & DI \\
\hline Age $\geq 36$ & 2 \\
\hline Age $<36$ & 0 \\
\hline Blood WBC $\geq 15000$ & 4 \\
\hline Blood WBC $<15000$ & 0 \\
\hline History of illness $\geq 6$ days & $(-5)$ \\
\hline History of illness $<6$ days & 0 \\
\hline CSF WBC $\geq 900$ ise & 3 \\
\hline CSF WBC $<900$ ise & 0 \\
\hline CSF $\%$ neutrophils $\geq 75$ & 4 \\
\hline CSF $\%$ neutrophils $<75$ & 0 \\
\hline Total score $\leq 4$ & TBM
\end{tabular}

CSF: Cerebrospinal fluid, DI: Diagnostic index, TBM: Tuberculous meningitis, WBC: White blood cell

dexamethasone therapy for 8 weeks in the presence of severe neurological deficits.

\section{RESULTS}

Patients over 18 years of age who presented the clinical picture of meningitis between 2015 and 2019 were assessed. TBM diagnosis was established based on clinical, CSF, radiological, and laboratory features. Viral, brucellar, and fungal etiologies were excluded by microscopic, serological, and molecular examinations of CSF and blood in all patients. Of the patients with TBM, 16 (80\%) were male, whereas the ages of patients ranged between 18 and 72 years (range, $39.05 \pm 15.52$ years). The most common symptoms were headache (90\%), altered consciousness (75\%), and neck rigidity (70\%). Convulsion (25\%), paresis/ plegia (25\%), and cranial nerve palsy (20\%) were the other neurological findings detected in the TBM cases. Twelve (60\%), five (25\%), and three (15\%) patients were assessed as stage II, stage III, and stage I, respectively. According to CSF analysis, $76 \%$ of patients had a CSF/blood glucose ratio below 0.3 and had a protein concentration above $100 \mathrm{mg} / \mathrm{dL}$, whereas pleocytosis $\left(>20 / \mathrm{mm}^{3}\right)$ was detected in $90 \%$ of patients. PCR and culture positivity rates were $45 \%$ separately, whereas five patients showed both culture and PCR positivity, four patients had only PCR, and four patients had only culture positivity. The rate of concomitant pulmonary TB was $25 \%$. Four (20\%) patients died despite antituberculous therapy. All patients were assessed as TBM according to TDSI (100\%), whereas five (25\%) and the remaining 15 (75\%) were considered as probable TBM and possible TBM according to MDSI. The scores were greater
Table 3. Marais' diagnostic scoring index (10)

Parameters

\begin{tabular}{|c|c|}
\hline Clinical criteria & Max score $=6$ \\
\hline Symptom duration more than 5 days & 4 \\
\hline $\begin{array}{l}\text { Systemic symptoms suggestive of TB (one or } \\
\text { more of the following): }\end{array}$ & \multirow{2}{*}{2} \\
\hline $\begin{array}{l}\text { Weight loss, night sweats, persistent cough }>2 \\
\text { weeks }\end{array}$ & \\
\hline $\begin{array}{l}\text { History of recent close contact with an individual } \\
\text { with pulmonary TB or positive TST or IGRA }\end{array}$ & 2 \\
\hline $\begin{array}{l}\text { Focal neurological deficit (excluding cranial nerve } \\
\text { palsies) }\end{array}$ & 1 \\
\hline Cranial nerve palsy & 1 \\
\hline Altered consciousness & 1 \\
\hline CSF criteria & Max score $=4$ \\
\hline Clear appearance & 1 \\
\hline Cells: $10-500$ per $\mu \mathrm{L}$ & 1 \\
\hline Lymphocytic predominance & 1 \\
\hline
\end{tabular}

CSF to plasma glucose ratio less than $50 \%$ or absolute CSF glucose less than $2.2 \mathrm{mmol} / \mathrm{L} \quad 1$

\begin{tabular}{ll}
\hline Cranial imaging criteria & Max score $=6$ \\
\hline Hydrocephalus & 1 \\
\hline Basal meningeal enhancement & 2 \\
\hline Tuberculoma & 2 \\
\hline Infarction & 1 \\
\hline Pre-contrast basal hyperdensity & 2 \\
\hline Evidence of TB elsewhere & Max score $=4$ \\
\hline $\begin{array}{l}\text { Chest radiograph suggestive of active TB: Signs } \\
\text { of TB = 2; miliary TB = 4 }\end{array}$ & $2 / 4$ \\
\hline CT/MRI/USG evidence for TB outside of CNS & 2 \\
\hline
\end{tabular}

AFB identified or Mycobacterium tuberculosis cultured from another source-

i.e., sputum, lymph node, gastric washing, urine, blood culture

Positive commercial M. tuberculosis NAAT from extra-neural specimen

4

\begin{tabular}{ll}
\hline Patients with no cranial imaging & \\
\hline Total score 6-9 & Possible \\
\hline Total score $\geq 10$ & Probable \\
\hline Patients with cranial CT/MRI & \\
\hline Total score 6-11 & Possible \\
\hline Total score $\geq 12$ & Probable \\
\hline
\end{tabular}

TB: Tuberculosis, CSF: Cerebrospinal fluid, CT/MRI/USG: Computed tomography/Magnetic resonance imaging/Ultrasonografi 
than or equal to 6 in all the cases with TBM by CPM, 13 of which were scored as 9 points (65\%).

Table 4 summarizes the cases with TBM and their outcomes according to TDSI, MDSI, and CPM criteria with additional findings supporting TBM.

\section{DISCUSSION}

Despite its decreased incidence in recent years, $T B$, particularly TBM, remains a leading cause of infectionrelated deaths worldwide. TBM is a severe and fatal disease that presents diagnostic and treatment difficulties. Antituberculous therapy prevents mortality and disability in less than half of the cases (14). A significant rate of morbidity and mortality related to TM results from the dysregulated immune response and delayed diagnosis and treatment $(15,16)$. Therefore, early and accurate TBM diagnosis remains of critical importance regarding disease eradication. Definitive diagnosis of TBM is based on isolation of Mycobacterium tuberculosis from CSF by staining and/ or culture or PCR techniques. However, the identification of the agent by culture or PCR techniques is not possible in every patient.

In this study, PCR or culture positivity was determined in only $45 \%$ of patients with TBM. Heemskerk et al. (17) have compared sensitivity levels of MDSI and other laboratory methods, including conventional Ziehl-Neelsen (ZN) staining, modified ZN staining, culture test, and Xpert PCR analysis for TBM diagnosis. Compared with MDSI, the sensitivity levels of the techniques mentioned above were $33.9 \%, 34.5 \%, 31.8 \%$, and $25.1 \%$, respectively. In another study conducted by Feng et al. (18), the sensitivity levels of the conventional and modified ZN procedures were compared with TB culture. They were determined to be 3.3\%

Table 4. The features of TBM cases according to three diagnostic indexes

\begin{tabular}{|c|c|c|c|c|c|c|c|c|c|c|c|c|c|c|c|c|}
\hline \multirow[b]{2}{*}{ Patients } & \multicolumn{6}{|c|}{ TDSI } & \multicolumn{5}{|l|}{ MDSI } & \multicolumn{5}{|l|}{ CPM } \\
\hline & 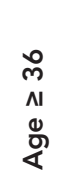 & 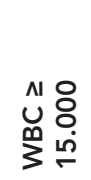 & 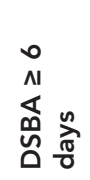 & 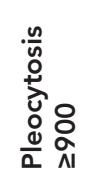 & 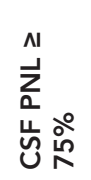 & 㐫 & 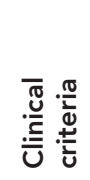 & $\begin{array}{l}\frac{\pi}{\frac{\pi}{2}} \\
\stackrel{\frac{\pi}{2}}{u} \\
\frac{U}{\tilde{U}}\end{array}$ & 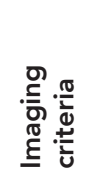 & $\sum_{\text {U }}^{\infty}$ & ڤั) & 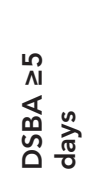 & 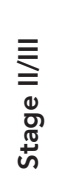 & 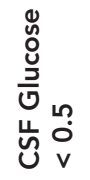 & 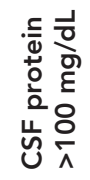 & 过 \\
\hline 1 & 0 & 0 & -5 & 0 & 0 & -5 & 5 & 4 & 0 & 0 & 9 & 3 & 0 & 3 & 1 & 7 \\
\hline 2 & 0 & 0 & -5 & 0 & 0 & -5 & 5 & 4 & 0 & 0 & 9 & 3 & 2 & 3 & 0 & 8 \\
\hline 3 & 0 & 0 & -5 & 3 & 0 & -2 & 5 & 4 & 0 & 0 & 9 & 3 & 2 & 3 & 1 & 9 \\
\hline-4 & 0 & 0 & -5 & 0 & 0 & -5 & 4 & 4 & 1 & 0 & 9 & 3 & 0 & 3 & 1 & 7 \\
\hline 5 & 0 & 0 & -5 & 0 & 0 & -5 & 5 & 3 & 0 & 0 & 8 & 3 & 2 & 0 & 1 & 6 \\
\hline 6 & 0 & 4 & -5 & 0 & 0 & -1 & 1 & 3 & 0 & 2 & 6 & 3 & 2 & 3 & 1 & 9 \\
\hline 7 & 0 & 0 & -5 & 0 & 0 & -5 & 5 & 4 & 2 & 2 & 13 & 3 & 2 & 3 & 1 & 9 \\
\hline 8 & 2 & 0 & -5 & 0 & 0 & -3 & 5 & 4 & 1 & 0 & 10 & 3 & 2 & 3 & 1 & 9 \\
\hline 9 & 2 & 0 & -5 & 0 & 0 & -3 & 6 & 3 & 0 & 4 & 13 & 3 & 2 & 3 & 1 & 9 \\
\hline 10 & 2 & 0 & -5 & 0 & 0 & -3 & 6 & 4 & 2 & 0 & 12 & 3 & 2 & 3 & 1 & 9 \\
\hline 11 & 2 & 0 & -5 & 0 & 0 & -3 & 5 & 4 & 3 & 2 & 14 & 3 & 2 & 3 & 1 & 9 \\
\hline 12 & 2 & 0 & -5 & 0 & 0 & -3 & 5 & 3 & 1 & 0 & 9 & 3 & 2 & 3 & 1 & 9 \\
\hline 13 & 0 & 0 & -5 & 0 & 0 & -5 & 4 & 4 & 1 & 2 & 11 & 3 & 0 & 3 & 0 & 6 \\
\hline 14 & 0 & 4 & 0 & 0 & 0 & 4 & 1 & 4 & 1 & 1 & 7 & 0 & 2 & 3 & 1 & 6 \\
\hline 15 & 0 & 0 & -5 & 0 & 0 & -5 & 6 & 3 & 2 & 0 & 11 & 3 & 2 & 3 & 1 & 9 \\
\hline 16 & 2 & 0 & -5 & 0 & 0 & -3 & 4 & 2 & 1 & 0 & 7 & 3 & 2 & 0 & 1 & 6 \\
\hline 17 & 2 & 4 & -5 & 0 & 0 & 1 & 5 & 4 & 2 & 0 & 11 & 3 & 2 & 3 & 1 & 9 \\
\hline 18 & 0 & & -5 & 0 & 0 & -5 & 6 & 4 & 2 & 2 & 14 & 3 & 2 & 3 & 1 & 9 \\
\hline 19 & 2 & 0 & -5 & 0 & 0 & -3 & 5 & 4 & 1 & 0 & 10 & 3 & 2 & 3 & 1 & 9 \\
\hline 20 & 2 & 0 & -5 & 0 & 0 & -3 & 2 & 4 & 0 & 0 & 6 & 3 & 2 & 3 & 1 & 9 \\
\hline
\end{tabular}

TDSI: Thwaites' diagnostic scoring indexes, TBM: Tuberculous meningitis, WBC: White blood cell 
and $82.9 \%$ versus $15.4 \%$, respectively. Hooker et al. (19) have determined that the rates of culture positivity assessed by the Löwenstein-Jensen and BACTEC methods were $20.7 \%$ and $35.7 \%$ in patients with TBM, respectively. Hence, ZN staining and culture methods are known as the cornerstone and gold standards for diagnosing TBM. However, their positivity rates do not exceed $60 \%$, even in the best-trained hands or best-equipped laboratories (18). According to a review by WHO in 2014, the nucleic acid test sensitivity rate was higher than that of culture methods for diagnosing TBM (80.5\% versus $62.8 \%$, respectively) (20). As a consequence, highly sensitive diagnostic tests for TBM remain elusive and impractical. Therefore, we need to improve affordable diagnostic methods or develop novel practical diagnostic approaches to achieve better TBM outcomes (21).

Clinical-based diagnostic approaches, such as TDSI, MDSI, and CPM, have been developed to eliminate these disadvantages, proven efficacy $(11,22-26)$. Sunbul et al. (23) have applied this method in 126 patients with TBM and reported it as practical, sensitive, and specific. In contrast, Sulaiman et al. (25) evaluated the TDSI method in 391 patients with TBM and detected it in $99 \%$ of cases. They reported that the TDSI method showed weak positivity in differentiating TBM from subacute meningitis and chronic meningitis. They also reported high specificity (99.1\%) despite having low sensitivity (1.2\%), whereas $50 \%$ of the 162 cases diagnosed with TBM were evaluated as either possible TBM or probable TBM, according to the MDSI method. The same study determined that MDSI was statistically significant in discriminating TBM from fungal and viral meningitis leading to chronic meningitis, except in undiagnosed subacute meningitis cases. A study conducted in our country found that all the TBM cases were scored according to TDSI, and $70 \%$ of patients had maximum scores (26). Likewise, in another study from our country, Erdem et al. (24) have analyzed both TDSI and MDSI methods and demonstrated that the TDSI method was effective in the cases with brucellar and tuberculous meningitis. The cases with TBM had statistically higher scores than those with brucellar meningitis assessed by MDSI. They found that the number of the cases classified as "probable" among the cases with TBM and "possible" among the cases with brucellar meningitis were higher when assessed by MDSI. Considering these results, they have noted that some cases with brucellar meningitis may be incorrectly diagnosed as TBM, according to both scoring indexes. Therefore, it is recommended to consider neurobrucellosis regarding etiology, particularly in chronic meningitis cases diagnosed with TBM in endemic regions, according to TDSI and MDSI. In addition, all the cases in our study had scores of $\leq 4$ by TDSI, whereas $75 \%$ and $25 \%$ of the 20 cases were classified in the possible and probable TBM categories by MDSI, respectively. However, in all our study patients categorized as possible TBM by MDSI, neurobrucellosis was excluded by serological and cultural methods.

A CPM developed by another study conducted in Romania presented a rapid clinical diagnostic model with good sensitivity and specificity to differentiate TBM from viral meningitis (11). This CPM model was evaluated in another study. This is a rapid clinical scoring method with a sensitivity of $96.7 \%$ and specificity of $81.1 \%$ in differentiating cases with TBM from those with viral meningitis by scores of $\geq 6$ (27). Similarly, the scores were greater than or equal to 6 in all TBM cases in our study by CPM, 13 of which scored 9 points (65\%). According to the outcomes of our study, the TDSI, MDSI, and CPM assessment methods are easily applicable and useful techniques for rapid and accurate TBM diagnosis.

\section{CONCLUSION}

Considering that available microbiological diagnostic methods used for TBM are impractical, time-consuming, and have low sensitivity, clinicians should use rapid diagnostic methods, such as TDSI, MDSI, or CPM to avoid complications due to delayed TBM diagnosis. An evaluation of the role of these valuable methods in the rapid and accurate TBM diagnosis by comprehensive studies involving larger sample sizes is needed.

\section{ETHICS}

Ethics Committee Approval: Ethics Committee approval was obtained from University of Health Sciences Turkey, Bakırköy Dr. Sadi Konuk Training and Research Hospital (2018/470; 2018-23-18).

Informed Consent: Patient consent forms were not obtained.

\section{Authorship Contributions}

Concept: K.K.Y., Design: Ş.N.K., Data Collection or Processing: Ş.N.K., G.Ü., S.Ş., E.C.Ü., R.K., Analysis or Interpretation: S..N.K., Literature Search: Ş.N.K., Writing: S..N.K., G.Ü., S.Ş.

Conflict of Interest: No conflict of interest was declared by the authors.

Financial Disclosure: The authors declared that this study received no financial support.

\section{REFERENCES}

1. Garg RK. Tuberculous meningitis. Acta Neurol Scand 2010;122:7590. 
2. Global tuberculosis report 2019.Geneva: World Health Organization, 2019. Available from: https://apps.who.int/iris/ bitstream/handle/10665/329368/9789241565714-eng.pdf?ua=1.

3. 2018 Report of Tuberculosis. Ankara, Turkey: Turkey Ministry of Health, Public Health Directorate, 2019.

4. Peto HM, Pratt RH, Harrington TA, LoBue PA, Armstrong LR. Epidemiology of extrapulmonary tuberculosis in the United States, 1993-2006. Clin Infect Dis 2009;49:1350-7.

5. Kalita J, Misra UK, Ranjan P. Predictors of long-term neurological sequelae of tuberculous meningitis: a multivariate analysis. Eur $J$ Neurol 2007;14:33-7.

6. Yasar KK, Pehlivanoglu F, Sengoz G. Predictors of mortality in tuberculous meningitis: a multivariate analysis of 160 cases. Int J Tuberc Lung Dis 2010;14:1330-5.

7. Garg RK. Microbiological diagnosis of tuberculous meningitis: Phenotype to genotype. Indian J Med Res 2019;150:448-57.

8. Thwaites G, Chau TT, Mai NT, Drobniewski F, McAdam K, Farrar J. Tuberculous meningitis. J Neurol Neurosurg Psychiatry 2000;68:289-99.

9. Thwaites GE, Chau TT, Stepniewska K, Phu NH, Chuong LV, Sinh DX, et al. Diagnosis of adult tuberculous meningitis by use of clinical and laboratory features. Lancet 2002;360:1287-92.

10. Marais S, Thwaites G, Schoeman JF, Török ME, Misra UK, Prasad K, et al. Tuberculous meningitis: a uniform case definition for use in clinical research. Lancet Infect Dis 2010;10:803-12.

11. Hristea A, Olaru ID, Baicus C, Moroti R, Arama V, Ion M. Clinical prediction rule for differentiating tuberculous from viral meningitis. Int J Tuberc Lung Dis 2012;16:793-8.

12. Yasar KK, Pehlivanoğlu F, Kehribar A, Şengöz G, Bakar M. Value of Thwaites'diagnostic scoring in the differentiation of tuberculous meningitis and acute bacterial meningitis. Flora 2011;16:32-7. Available from: https://www.acarindex.com/flora-i-nfeksiyonhastaliklari-ve-klinik-mikrobiyoloji-dergisi/thwaites-in-diagnostikskorlamasinin-akut-bakteriyel-ve-tuberkuloz-menenjitli-hastalarinayirici-tanisindaki-degeri-240576

13. STREPTOMYCIN treatment of tuberculous meningitis. Lancet. 1948;1:582-96.

14. Be NA, Kim KS, Bishai WR, Jain SK. Pathogenesis of central nervous system tuberculosis. Curr Mol Med 2009;9:94-9.

15. Davis AG, Rohlwink UK, Proust A, Figaji AA, Wilkinson RJ. The pathogenesis of tuberculous meningitis. J Leukoc Biol 2019;105:267-80.
16. Hosoglu S, Geyik MF, Balik I, Aygen B, Erol S, Aygencel TG, et al. Predictors of outcome in patients with tuberculous meningitis. Int $\mathrm{J}$ Tuberc Lung Dis 2002;6:64-70.

17. Heemskerk AD, Donovan J, Thu DDA, Marais S, Chaidir L, Dung VTM, et al. Improving the microbiological diagnosis of tuberculous meningitis: A prospective, international, multicentre comparison of conventional and modified Ziehl-Neelsen stain, GeneXpert, and culture of cerebrospinal fluid. J Infect 2018;77:509-15.

18. Feng GD, Shi M, Ma L, Chen P, Wang BJ, Zhang M, et al. Diagnostic accuracy of intracellular mycobacterium tuberculosis detection for tuberculous meningitis. Am J Respir Crit Care Med 2014;189:47581.

19. Hooker JA, Muhindi DW, Amayo EO, Mc'ligeyo SO, Bhatt KM, Odhiambo JA. Diagnostic utility of cerebrospinal fluid studies in patients with clinically suspected tuberculous meningitis. Int $\mathrm{J}$ Tuberc Lung Dis 2003;7:787-96.

20. Foppiano Palacios C, Saleeb PG. Challenges in the diagnosis of tuberculous meningitis. J Clin Tuberc Other Mycobact Dis 2020;20:100164.

21. Donovan J, Thwaites GE, Huynh J. Tuberculous meningitis: where to from here? Curr Opin Infect Dis 2020;33:259-66.

22. Török ME, Nghia HD, Chau TT, Mai NT, Thwaites GE, Stepniewska $\mathrm{K}$, et al. Validation of a diagnostic algorithm for adult tuberculous meningitis. Am J Trop Med Hyg 2007;77:555-9.

23. Sunbul M, Atilla A, Esen S, Eroglu C, Leblebicioglu H. Thwaites' diagnostic scoring and the prediction of tuberculous meningitis. Med Princ Pract 2005;14:151-4.

24. Erdem H, Senbayrak S, Gencer S, Hasbun R, Karahocagil MK, Sengoz $G$, et al. Tuberculous and brucellosis meningitis differential diagnosis. Travel Med Infect Dis 2015;13:185-91.

25. Sulaiman T, Medi S, Erdem H, Senbayrak S, Ozturk-Engin D, Inan A, et al. The diagnostic utility of the "Thwaites' system" and "lancet consensus scoring system" in tuberculous vs. non-tuberculous subacute and chronic meningitis: multicenter analysis of 395 adult patients. BMC Infect Dis 2020;20:788.

26. Pehlivanoglu F, Yasar KK, Sengoz G. Tuberculous meningitis in adults: a review of 160 cases. ScientificWorldJournal 2012;2012:169028.

27. Jipa R, Olaru ID, Manea E, Merisor S, Hristea A. Rapid Clinical Score for the Diagnosis of Tuberculous Meningitis: A Retrospective Cohort Study. Ann Indian Acad Neurol 2017;20:363-6. 